\title{
EFFORTS TO IMPROVE STUDENT LEARNING ACTIVITIES THROUGH THE PROVISION OF INFORMATION SERVICES IN SMPN 2 METRO IN LESSON 2013/2014
}

\author{
Tukilah \\ SMP Negeri 2 Metro \\ tukilahsmpn2metro@gmail.com
}

\begin{abstract}
Goals to be achieved researchers that want to know the provision of information services can improve students' learning activities in class VII SMP Negeri 2 Metro Semester Academic Year 2013/2014. The design of this research using action research service. The subject in this study is a Class VII the number of students is 20 students. The results of this study, it can be concluded that the information services in improving student learning activities Class VII SMP Negeri 2 Metro is we can see from this change in behavior of students there is an increase in students' learning activities that occur on the first cycle of $39.5 \%$ and the second cycle by $76 \%$, resulting in an increase of $36.5 \%$.
\end{abstract}

Keywords: learning activities, information services, smp negeri 2 metro

\section{PENDAHULUAN}

Dalam keseluruhan proses pendidikan di sekolah, kegiatan belajar merupakan kegiatan yang paling pokok. Ini berarti berhasil tidaknya perencanaan tujuan pendidikan banyak bergantung kepada bagaimana proses belajar yang dialami oleh murid sebagai anak didik. Kegiatan belajar mengajar mempunyai makna dan pengertian yang lebih luas dari pada pengertian mengajar dalam proses belajar mengajar tersirat adanya suatu kesatuan kegiatan yang tak terpisahkan antara siswa yang belajar dan guru yang mengajar,antara kedua kegitan ini terjalin interaksi yang saling menunjang.

Dewasa ini banyak sekali pertanyaan yang dilontarkan mengapa dalam belajar diperlukan aktivitas? Sebab pada prinsipnya belajar adalah berbuat. Berbuat untuk mengubah tingkah laku, jadi memerlukan kegiatan. Tidak ada belajar kalau tidak ada aktivitas belajar. Itulah sebabnya aktivitas merupakan prinsip atau asas yang sangat penting dalam interaksi belajar-mengajar. Sebagai rasionalitasnya hal ini mendapatkan pengakuan dari berbagai ahli pendidikan.

Prinsip-prinsip aktivitas dalam belajar dalam hal ini akan dilihat dari sudut pandang perkembangan konsep jiwa menurut ilmu jiwa. Dengan melihat unsur kejiwaan seseorang subjek belajar/subjek didik, dapatlah diketahui bagaimana prinsip aktivitas yang terjadi dalam belajar itu. Karena dilihat dari sudut pandang ilmu jiwa, maka sudah barang tentu yang menjadi fokus perhatian adalah komponen manusiawi yang melakukan aktivitas dalam pembelajaran, yakni siswa dan guru.

Prestasi yang tinggi merupakan target yang ingin dicapai dalam belajar, namun hal itu tidak dapat di peroleh tanpa adanya semangat dan ketekunan dalam belajar. Aktivitas belajar yang dilakukan oleh siswa merupakan salah satu syarat wajib dalam mencapai keberhasilan dalam belajar. Sekarang ini para siswa masih banyak yang kurang dan bahkan tidak memperhatikan lagi masalah aktivitas 
mereka dalam belajar, hal ini lah yang menjadi kendala mereka dalam mencapai keberhasilan belajar.

Aktivitas belajar pada setiap siswa pada dasarnya tidak sama, ada siswa yang aktivitas belajarnya lancar, kadang-kadang lancar, dan ada juga yang aktivitas belajarnya sulit. Kondisi seperti ini lah yang menjadi masalah penting dalam berlangsungnya kegiatan belajar, maka perlunya penyelesaian masalah tersebut mutlak diperlukan agar dapat tercapainya prestasi belajar yang diharapkan.Dalam mencapai keberhasilan belajar sangat didukung oleh aktivitas belajar yang ditunjukan oleh siswa atau peserta didik dalam melakukan proses pembelajaran, oleh karena itu siswa dituntut untuk tidak melakukan aktivitas yang di luar konstek pembelajaran selama berlangsung.

Menurut Ahmadi (2004: 77) Aktivitas belajar bagi setiap inidividu, tidak selamanya dapat berlangsung secara wajar, kadang-kadang lancar, kadang-kadang tidak, kadang-kadang dapat cepat menangkap apa yang di pelajari, kadangkadang terasa amat sulit. Dalam hal semangat terkadang semangatnya tinggi, tetapi terkadang juga sulit untuk mengadakan konsentrasi.

Pemberian layanan bimbingan dan konseling merupakan salah satu cara dalam meningkatkan aktivitas belajar bagi siswa. Layanan dalam bimbingan dan konseling sangatlah beragam dan banyak jenisnya tergantung pada guru pembimbing dalam pemberian layanan bimbingan dan konseling mau menggunakan layanan yang seperti apa, tergantung pada tingkat kebutuhan siswa di sekolah. Guru pembimbing harus secara sigap dan tepat dalam mengidentifikasi masalah dan tingkat kebutuhan siswa dalam layanan bimbingan dan konseling.

Berdasarkan hasil prasurvey yang dilakukan oleh peneliti di KELAS VIISMP Negeri 2 Metro pada Tanggal 13-14 Juli
2013, terdapat 20 siswa dalam satu kelas, maka diperoleh data tentang siswa yang mengalami masalah tentang aktivitas belajar yang rendah sebagai berikut:

Tabel 1. Rekapitulasi Data Siswa Tentang Masalah Aktivitas Belajar

\begin{tabular}{llc}
\hline No & \multicolumn{1}{c}{ Jenis Masalah } & Jml \\
\hline $\mathbf{1}$ & $\begin{array}{l}\text { Siswa kurang } \\
\text { mendengarkan penjelasan } \\
\text { guru }\end{array}$ & 4 \\
\hline $\mathbf{2}$ & $\begin{array}{l}\text { Siswa tidak } \\
\text { memperhatikan/menyimak } \\
\text { penjelasan guru }\end{array}$ & 4 \\
\hline 3 & $\begin{array}{l}\text { Siswa tidak mencatat apa } \\
\text { yang disampaikan guru }\end{array}$ & 4 \\
\hline 4 & $\begin{array}{l}\text { Siswa tidak mengerjakan } \\
\text { tugas yang diberikan oleh } \\
\text { guru }\end{array}$ & 4 \\
\hline 5 & $\begin{array}{l}\text { Siswa tidak membuat } \\
\text { rangkuman dari materi yang } \\
\text { disampaikan oleh guru }\end{array}$ & 4 \\
\hline Total & $\mathbf{2 0}$ \\
\hline
\end{tabular}

Berdasarkan data dari tabel diatas, maka diperoleh data siswa yang mengalami masalah dalam aktivitas belajar adalah sejumlah 20 siswa dalam satu KELAS VII SMP Negeri 2 Metro. Faktor-faktor yang menyebabkan masalah aktivitas belajar siswa yang peneliti temukan adalah:

1. Susahnya siswa dalam memahami penjelasan dari guru

2. Siswa memiliki persepsi negative kapada guru

3. Penjelasan yang disampaikan oleh guru tidak sesuai dengan materi yang diberikan kepada siswa

Masalah aktivitas belajar yang dialami oleh para siswa di KELAS VII SMP Negeri 2 Metro secara garis besar dapat dientaskan dengan pemberian layanan bimbingan dan konseling. Layanan konseling yang dapat diberikan dalam mengatasi masalah aktivitas belajar siswa tersebut adalah dengan pemberian layanan:
1. Layanan Informasi
2. Layanan Bimbingan Kelompok 


\section{Layanan Konseling Kelompok}

\section{METODE}

Rancangan dalam penelitian ini menggunakan pendekatan penelitian tindakan (action research). Menurut Kemmis 1990 dalam Hidayat (2012: 18) Mengajukan sebuah model penelitian tindakan kelas. Model yang diajukan kemmis pada dasarnya tidak jauh berbeda dengan model yang dikemukakan oleh Levin. Bahkan dapat dikatakan, model Kemmis adalah pengembangan model penelitian tindakan Levin.

Kemmis mengajukan sebuah model penelitian tindakan kelas, dengan menjelaskan lebih detail bagian-bagian yang ada dalam model spiral dari Levin. Levin menjelaskan bahwa dalam spiral penelitian tindakan kelas terdapat tiga proses meliputi: perencanaan (planning), pelaksanaan (execution), dan refleksi

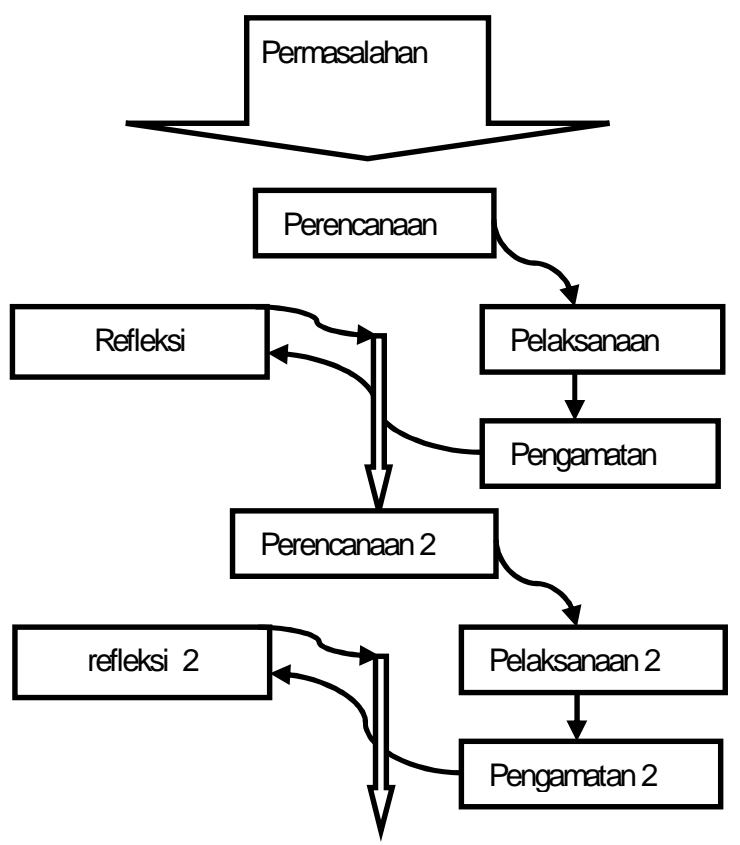

(reconnaissance).

Gambar 1. Alur Penelitian Tindakan

Dalam hal ini yang menjadi alat dalam penelitian adalah layanan bimbingan dan konseling berupa layanan informasi, sedangkan yang menjadi masalah adalah aktivitas belajar siswa. Penggunaan layanan informasi diharapkan nantinya dapat meningkatkan aktivitas belajar siswa yang selama ini dinilai kurang aktif dalam proses pembelajaran dapat menjadi aktif dalam proses pembelajaran.

Berikut peneliti akan memberikan gambaran mengenai proses penelitian tindakan yang peneliti ambil dalam melakukan penelitian tergambar pada Gambar 1.

\section{HASIL DAN PEMBAHASAN}

\section{Aktivitas Belajar Siswa}

Pelaksanaan layanan informasi dalam meningkatkan aktivitas belajar siswa pada siklus I (pertemuan 1), siklus II (pertemuan 2), silkus II (pertemuan 1), dan siklus II (pertemuan 2) mendapatkan hasil yang sangat memuaskan, data yang peneliti peroleh tertera pada Table 2.

Berdasarkan data Table 2, dapat dilihat bahwa aktivitas belajar siswa setiap pertemuan mengalami peningkatan. Hal ini dapat dilihat dari table hasil pengamatan pada siklus I dan siklus II yang terjadi peningkatan pada setiap aspek.

\section{a. Mendengarkan penjelasan peneliti}

Pada aspek mendengarkan penjelasan guru terjadi peningkatan pada siklus I dan siklus II. Pada siklus I nilai dari hasil rata-rata pada setiap pertemuan mengalami peningkatan yaitu sebesar 37.5\%. Sedangkan pada siklus II jauh lebih meningkat dari masing-masing pertemuan yang nilai rata-ratanya adalah sebesar 77.5\%. Peningkatan ini dikarenakan para siswa lebih memperhatikan peneliti dalam mengikuti layanan informasi dalam menyampaikan materi. Setelah beberapa kali mengikuti kegiatan layanan informasi yang disampaikan peneliti, para siswa lebih bisa mengikuti pelajaran/layanan dalam 
Tabel 2. Rekapitulasi Data Aktivitas Belajar Pada Kegiatan Siklus I Dan Siklus II

\begin{tabular}{|c|c|c|c|c|c|c|c|c|}
\hline \multirow[t]{2}{*}{ No } & \multirow{2}{*}{$\begin{array}{c}\text { Aspek Aktivitas Belajar Yang } \\
\text { Diamati }\end{array}$} & \multicolumn{2}{|c|}{ Siklus I } & \multirow{2}{*}{$\begin{array}{l}\text { Rata- } \\
\text { rata }\end{array}$} & \multicolumn{2}{|c|}{ Siklus II } & \multirow{2}{*}{$\begin{array}{l}\text { Rata- } \\
\text { rata }\end{array}$} & \multirow[t]{2}{*}{ Target } \\
\hline & & 1 & 2 & & 1 & 2 & & \\
\hline 1 & $\begin{array}{l}\text { Siswa dapat mendengarkan } \\
\text { penjelasan peneliti }\end{array}$ & $25 \%$ & $50 \%$ & $37.5 \%$ & $70 \%$ & $85 \%$ & $77.5 \%$ & $75 \%$ \\
\hline 2 & $\begin{array}{lcc}\text { Siswa dapat } & \text { memperhatikan } \\
\text { penjelasan peneliti } & \\
\end{array}$ & $30 \%$ & $55 \%$ & $42.5 \%$ & $65 \%$ & $90 \%$ & $77.5 \%$ & $75 \%$ \\
\hline 3 & $\begin{array}{l}\text { Siswa dapat mencatat materi yang } \\
\text { disampaikan oleh peneliti }\end{array}$ & $30 \%$ & $50 \%$ & $40 \%$ & $70 \%$ & $80 \%$ & $75 \%$ & $75 \%$ \\
\hline 4 & $\begin{array}{l}\text { Siswa dapat mengerjakan tugas yang } \\
\text { diamanatkan oleh peneliti }\end{array}$ & $30 \%$ & $55 \%$ & $42.5 \%$ & $70 \%$ & $80 \%$ & $75 \%$ & $75 \%$ \\
\hline 5 & $\begin{array}{l}\text { Siswa dapat membuat ringkasan dari } \\
\text { materi yang disampaikan peneliti }\end{array}$ & $20 \%$ & $50 \%$ & $35 \%$ & $65 \%$ & $80 \%$ & $75 \%$ & $75 \%$ \\
\hline Jul & lah & & & $197.5 \%$ & & & $380 \%$ & \\
\hline Rat & -rata & & & $39.5 \%$ & & & $76 \%$ & \\
\hline
\end{tabular}

mendengarkan penjelasan dari peneliti. Peningkatan ini dapat kita lihat pada aktivitas siswa yaitu:

1) Ketika peneliti mengajukan pertannyaan siswa semakin banyak yang dapat menjawab pertannyaan yang diberikan oleh peneliti.

2) Ketika peneliti menjelaskan materi siswa dapat menjelaskan kembali materi yang telah disampaikan oleh peneliti.

3) Siswa dapat mengajukan petannyaan dengan percaya diri kepada peneliti seputar materi yang disampaikan.

4) Siswa lebih sigap dan tanggap lagi dalam sesi diskusi yang dilakukan oleh peneliti.

Peneliti berasumsi bahwa pemberian layanan informasi dari siklus I sampai ke siklus II pada aspek ini meningkat dari $37.5 \%$ menjadi $77.5 \%$, peningkatan yang terjadi adalah sebesar 40\%. Karena rata-rata pada aspek ini pada siklus II telah memenuhi criteria keberhasilan yaitu $75 \%$ maka aspek ini telah memenuhi target.

\section{b. Memperhatikan penjelasan peneliti}

Pada aspek memperhatikan penjelasan guru terjadi peningkatan pada siklus I dan siklus II. Pada siklus I nilai dari hasil rata-rata pada setiap pertemuan mengalami peningkatan yaitu sebesar 42.5\%. Sedangkan pada siklus II jauh lebih meningkat dari masing-masing pertemuan yang nilai rata-ratanya adalah sebesar 77.5\%. Peningkatan ini dikarenakan para siswa lebih memperhatikan peneliti dalam mengikuti layanan informasi dalam menyampaikan materi. Setelah beberapa kali mengikuti kegiatan layanan informasi yang disampaikan peneliti, para siswa lebih bisa mengikuti pelajaran/layanan dalam mendengarkan penjelasan dari peneliti. Peningkatan ini dapat dilihat pada aktivitas siswa yaitu:

1) Ketika peneliti menjelaskan materi siswa dapat menjelaskan kembali materi yang telah disampaikan oleh peneliti.

2) Siswa dapat mengajukan petannyaan dengan percaya diri kepada peneliti seputar materi yang disampaikan.

3) Siswa lebih sigap dan tanggap lagi dalam sesi diskusi yang dilakukan oleh peneliti.

Peneliti berasumsi bahwa pemberian layanan informasi dari siklus I sampai ke siklus II pada aspek ini meningkat dari $42.5 \%$ menjadi $77.5 \%$, peningkatan yang terjadi adalah sebesar $35 \%$. Karena rata-rata pada aspek ini pada siklus II telah memenuhi criteria 
keberhasilan yaitu $75 \%$ maka aspek ini telah memenuhi target.

\section{c. Mencatat materi yang disampaikan oleh peneliti}

Pada aspek mencatat materi yang disampaikan oleh guru terjadi peningkatan pada siklus I dan siklus II. Pada siklus I nilai dari hasil rata-rata pada setiap pertemuan mengalami peningkatan yaitu sebesar 40\%. Sedangkan pada siklus II jauh lebih meningkat dari masing-masing pertemuan yang nilai rata-ratanya adalah sebesar $75 \%$. Peningkatan ini disebabkan para siswa lebih memperhatikan peneliti dalam mencatat materi yang disampaikan oleh peneliti, karena peneliti menyampaikan materi dari point per point. Setelah beberapa kali mengikuti kegiatan layanan informasi yang disampaikan peneliti, para siswa lebih bisa mengikuti pelajaran/layanan dalam mendengarkan penjelasan dari peneliti.

Peneliti berasumsi bahwa pemberian layanan informasi dari siklus I sampai kesiklus II pada aspek ini meningkat dari 40\% menjadi $75 \%$, peningkatan yang terjadi adalah sebesar $35 \%$. Karena rata-rata pada aspek ini pada siklus II telah memenuhi criteria keberhasilan yaitu $75 \%$ maka aspek ini telah memenuhi target.

d. Mengerjakan tugas yang diamanatkan oleh peneliti

Pada aspek mengerjakan tugas yang disampaikan oleh guru terjadi peningkatan pada siklus I dan siklus II. Pada siklus I nilai dari hasil rata-rata pada setiap pertemuan mengalami peningkatan yaitu sebesar $42 \%$. Sedangkan pada siklus II jauh lebih meningkat dari masingmasing pertemuan yang nilai rata-ratanya adalah sebesar 75\%. Peningkatan ini disebabkan para siswa lebih memperhatikan peneliti dalam mengerjakan tugas. Setelah beberapa kali mengikuti kegiatan layanan informasi yang disampaikan peneliti, para siswa lebih bisa mengikuti pelajaran/layanan dalam mendengarkan penjelasan dari peneliti.

Peneliti berasumsi bahwa pemberian layanan informasi dari siklus I sampai ke siklus II pada aspek ini meningkat dari $42 \%$ menjadi $75 \%$, peningkatan yang terjadi adalah sebesar $33 \%$. Karena rata-rata pada aspek ini pada siklus II telah memenuhi criteria keberhasilan yaitu $75 \%$ maka aspek ini telah memenuhi target.

e. Membuat ringkasan dari materi yang disampaikan peneliti

Pada aspek membuat ringkasan yang disampaikan oleh guru terjadi peningkatan pada siklus I dan siklus II. Pada siklus I nilai dari hasil rata-rata pada setiap pertemuan mengalami peningkatan yaitu sebesar 35\%. Sedangkan pada siklus II jauh lebih meningkat dari masingmasing pertemuan yang nilai rata-ratanya adalah sebesar 75\%. Peningkatan ini disebabkan para siswa lebih memperhatikan peneliti dalam merangkum materi yang disampaikan oleh guru secara maksimal. Setelah beberapa kali mengikuti kegiatan layanan informasi yang disampaikan peneliti, para siswa lebih bisa mengikuti pelajaran/layanan dalam mendengarkan penjelasan dari peneliti.

Peneliti berasumsi bahwa pemberian layanan informasi dari siklus I sampai ke siklus II pada aspek ini meningkat dari $35 \%$ menjadi $75 \%$, peningkatan yang terjadi adalah sebesar 40\%. Karena rata-rata pada aspek ini pada siklus II telah memenuhi criteria keberhasilan yaitu $75 \%$ maka aspek ini telah memenuhi target. 


\section{Efektivitas Layanan Informasi}

Dalam pengentasan masalah aktivitas belajar melalui layanan informasi dapat berhasi secara efektif, hal ini terlihat dari peningkatan dalam setiap aspeknya. Berikut ini adalah data efektifitas pelaksanaan layanan informasi untuk pengentasan masalah aktivitas belajar pada pelaksanaan siklus I dilihat dari presentase yaitu sebesar $39.5 \%$ dan pada siklus II sebesar $76.7 \%$, sehingga terjadi peningkatan sebesar $37.2 \%$. Target yang telah ditetapka adalah sebesar $75 \%$ dan pada penelitian ini dilaksanakan sebanyak II siklus dan pada pertemuan terakhir siklus yang ke II ini mencapai rata-rata $76 \%$, oleh karena itu penelitian ini telah berhasil. Hasil yang peneliti harapkan dalam penelitian ini pengentasan masalah aktivitas belajar malalui pemberian layanan informasi dapat berhasil secara efektif.

\section{Meningkatkan Aktivitas Belajar Siswa Melalui Layanan Informasi}

Penelitian ini dilakukan dengan memanfaatkan pemberian layanan informasi dalam meningkatkan aktivitas belajar siswa yang dilakukan di Kelas VII SMP Negeri 2 Metro. Layanan informasi dapat dilaksanakan dengan efektif dan aktivitas belajar siswa pun mengalami peningkatan yang terjadi pada setiap siklusnya, siklus I dengan jumlah rata-rata skor $39.5 \%$, sedangkan pada siklus II dengan jumlah rata-rata skor $76.7 \%$. Kriteria yang ditetapkan oleh peneliti adalah sebesar $75 \%$, jadi penelitian ini telah mencapai target dalam penelitian ini dengan hasil yang maksimal dan efektif. Senada dari apa yang telah di tetapkan dalam Peraturan Pemerintah No.19 Tahun 2005 Tentang Standar Pendidikan Nasional yaitu sebasar 75\%.

\section{Aktivitas Belajar Siswa dalam Mengikuti Pelajaran}

Hasil data yang peneliti peroleh dalam melakukan pengamatan kepada siswa pada saat megikuti pelajaran bahasa Indonesia, seperti yang telah peneliti uraikan diatas bahwa siswa mengalami peningkatan dalam mengikuti pelajaran yang disampaikan oleh guru mata pelajaran Indonesia. Peningkatan yang terjadi pada setiap aspek aktivitas belajar dengan rata-rata sebersar $41 \%$ dari hasil pengamatan ke 1 sebesar $36 \%$ dan pengamatan ke 2 sebesar $77 \%$.

Setelah peneliti mengamati aktivitas belajar siswa pada saat mengikuti pelajaran sebanyak dua kali yaitu pada mata pelajaran bahasa Indonesia, maka peneliti dapat menyimpulkan bahwa pada aspek aktivitas belajar yaitu (Tabel 3):

a. Siswa dapat mendengarkan penjelasan guru

Para siswa telah mengalami peningkatan sebesar $42.5 \%$ (8.5 siswa) yang pada pengamatan ke 1 diperoleh data siswa sebesar 40\% (8 siswa) dan kemudian dilakukan pengamatan ke 2 maka diperoleh data siswa sebesar 80\% (16 siswa). Oleh karena itu pada aspek ini telah memenuhi criteria yang ditetapkan sebesar $75 \%$.

b. Siswa dapat memperhatikan penjelasan guru

Para siswa telah mengalami peningkatan sebesar 40\% (8 siswa) yang pada pengamatan ke 1 diperoleh data siswa sebesar 40\% (8 siswa) dan kemudian dilakukan pengamatan ke 2 maka diperoleh data siswa sebesar 80\% (16 siswa). Oleh karena itu pada aspek ini telah memenuhi criteria yang ditetapkan sebesar $75 \%$. 
Tabel 3. Rekapitulasi Data Aktivitas Belajar Siswa Pada Saat Mengikuti Pelajaran

\begin{tabular}{llcccc}
\hline No & $\begin{array}{l}\text { Aspek Aktivitas Belajar Yang } \\
\text { Diamati }\end{array}$ & \multicolumn{2}{c}{ Pengamatan } & Peningkatan & Persen \\
\cline { 2 - 4 } & $\mathbf{1}$ & $\mathbf{2}$ & & \\
\hline $\mathbf{1}$ & $\begin{array}{l}\text { Siswa dapat mendengarkan penjelasan } \\
\text { guru }\end{array}$ & 8 & 16 & 8 & $40 \%$ \\
\hline $\mathbf{2}$ & $\begin{array}{l}\text { Siswa dapat memperhatikan } \\
\text { penjelasan guru }\end{array}$ & 8 & 16 & 8 & $40 \%$ \\
\hline 3 & $\begin{array}{l}\text { Siswa dapat mencatat materiyang } \\
\text { disampaikan oleh guru }\end{array}$ & 7 & 15 & 8 & $40 \%$ \\
\hline 4 & $\begin{array}{l}\text { Siswa dapat mengerjakan tugas yang } \\
\text { diamanatkan oleh guru }\end{array}$ & 7 & 15 & 8 & $40 \%$ \\
\hline 5 & $\begin{array}{l}\text { Siswa dapat membuat ringkasan dari } \\
\text { materiyang disampaikanguru }\end{array}$ & 6 & 15 & 9 & $45 \%$ \\
\hline Jumlah & $\mathbf{3 6}$ & 77 & $\mathbf{4 1}$ & $\mathbf{2 0 5 \%}$ \\
\hline Rata-rata & 7 & $\mathbf{1 5}$ & $\mathbf{8}$ & $\mathbf{4 1 \%}$ \\
\hline
\end{tabular}

c. Siswa dapat mencatat materi yang disampaikan oleh guru

Para siswa telah mengalami peningkatan sebesar 40\% (8 siswa) yang pada pengamatan ke 1 diperoleh data siswa sebesar $35 \%$ (7 siswa) dan kemudian dilakukan pengamatan ke 2 maka diperoleh data siswa sebesar $75 \% \quad(15$ siswa). Oleh karena itu pada aspek ini telah memenuhi criteria yang ditetapkan sebesar $75 \%$.

\section{d. Siswa dapat mengerjakan tugas yang diamanatkan oleh guru}

Para siswa telah mengalami peningkatan sebesar 40\% (8 siswa) yang pada pengamatan ke 1 diperoleh data siswa sebesar $35 \%$ (7 siswa) dan kemudian dilakukan pengamatan ke 2 maka diperoleh data siswa sebesar $75 \% \quad(15$ siswa). Oleh karena itu pada aspek ini telah memenuhi criteria yang ditetapkan sebesar $75 \%$.

\section{e. Siswa dapat membuat ringkasan dari materi yang disampaikan guru}

Para siswa telah mengalami peningkatan sebesar 45\% (9 siswa) yang pada pengamatan ke 1 diperoleh data siswa sebesar 30\% (6 siswa) dan kemudian dilakukan pengamatan ke 2 maka diperoleh data siswa sebesar 75\% (15 siswa). Oleh karena itu pada aspek ini telah memenuhi criteria yang ditetapkan sebesar $75 \%$.

\section{KESIMPULAN}

Berdasarkan kerangka teoritik dan temuan hasil analisis dari penelitian tersebut, maka dapat disimpulkan bahwa pemberian layanan informasi dapat meningkatkan aktivitas belajar khususnya siswa di SMP Negeri 2 Metro. Simpulan tersebut ditunjukan dari hasil temuan analisis sebagai berikut:

1. Respon siswa dalam mengikuti kegiatan layanan informasi dalam meningkatkan aktivitas belajar siswa di KELAS VII SMP Negeri 2 Metro Semester Genap Tahun Pelajaran 2013/2014 sangat positif dan terjadi timbal balik kepada peneliti sehingga dalam suasana kegiatan layanan informasi antara peneliti dan para siswa terjalin komunikasi aktif yang saling melengkapi satu dengan yang lainnya.

2. Melalui pemberian layanan informasi kepada siswa yang dilakukan oleh peneliti untuk meningkatkan aktivitas belajar di KELAS VII SMP Negeri 2 Metro Semester Genap Tahun Pelajaran 2013/2014 adalah terdapatnya peningkatan aktivitas belajar siswa yang peneliti lihat dari siklus I dengan rata-rata sebesar $39.5 \%$ dan pada siklus II dengan rata-rata sebesar $76 \%$ sehingga terjadi sebuah peningkatan sebesar $36.5 \%$. 


\section{DAFTAR PUSTAKA}

Ahmadi, Abu. 2004. Psikologi Belajar. Jakarta : PT. Rineka Cipta.

Arikunto, Suharsimi. 2010. Prosedur Penelitian Suatu Pendekatan Praktik. Jakarta : PT Rineka Cipta.

Hidayat, Dede Rahmat. ddk. 2012. Penelitian Tindakan Dalam Bimbingan Dan Konseling. Jakarta Barat : PT. Indeks.

Juntika Nurihsan, Achmad. 2009. Strategi Layanan Bimbingan Dan Konseling . Bandung : PT Refika Aditama.

Karwono. ddk. 2010. Belajar Dan Pembelajaran Serta Pemanfaatan Sumber Belajar. Ciputat. PT Cerdas Jaya.

Ketut Sukardi, Dewa. 2008. Pengantar Pelaksanaan Program Bimbingan dan Konseling Di Sekolah. Jakarta: PT. Rineka Cipta.

Nasution. 2012. Psikologi Belajar. Aktivitas Belajar. (Oneline). No.3.dari http.//.www.google.com.Jakarta.ac. id. diunduh 2 September 2012.

Prayitno, ddk. 2002. Pelayanan Bimbingan Dan Konseling Berbasis Kompetansi. Jakarta: Pusat Kurikulum Balitbang Depdiknas.

Prayitno. 2004. Seri Layanan Konseling L.1 - L.9. Padang : Universitas Negri Padang.

Purwanto. 2012. Psikologi Belajar. Dari http:// shoendhawa. blogspot.com 2012/07/ menumbuhkan-motivasibelajar.html. diunduh Juli 2012.

Sardiman. 2011. Interksi Dan Motivasi Belajar Mengajar. Jakarta : PT Raja Grafindo Persada.

Sudrajat. 2012. Interaksi Belajar. (blogspot.com.//.http://treseent.wo rdpress.com / category/aktivitas
belajar/Egi.2009. aktivitas belajar http://regiamanah.blogspo.com /... / aktivitas belajar -oleh.html).

Sugiyono. 2010. Metode Penelitian Kuantitatif Dan Kualitatif Dan $R \& D$. Bandung : Alfabeta.

Suwarjo, ddk. 2010. 55 Permainan Dalam Bimbingan Dan Konseling. Yogyakarta: Paramita Publishing.

Tohirin. 2007. Bimbingan Dan Konseling Di Sekolah Dan Madrasah (Berbasis Integrasi). Jakarta : PT Raja Grafindo Persada. 